Meta

Journal des traducteurs

Translators' Journal

\title{
Moving In-Between: The Interpreter as Ethnographer and the Interpreting-Researcher as Anthropologist
}

\section{Şebnem Bahadır}

Volume 49, numéro 4, décembre 2004

URI : https://id.erudit.org/iderudit/009783ar

DOI : https://doi.org/10.7202/009783ar

Aller au sommaire du numéro

\section{Éditeur(s)}

Les Presses de l'Université de Montréal

ISSN

0026-0452 (imprimé)

1492-1421 (numérique)

Découvrir la revue

Citer cet article

Bahadır, S. (2004). Moving In-Between: The Interpreter as Ethnographer and the Interpreting-Researcher as Anthropologist. Meta, 49(4), 805-821.

https://doi.org/10.7202/009783ar

\section{Résumé de l'article}

Dans les domaines du droit, de la santé et des services sociaux, l'interprète communautaire se voit confronté à des problèmes éthiques particulièrement délicats. Tout en recherchant un cadre théorique adéquat pouvant expliquer les rôles sociaux et les identités culturelles de l'interprétation communautaire, j'ai entrepris une re-lecture du sociologue et interprète de conférence allemand Heinz Göhring. Ses articles se situent entre les disciplines allemandes comme langue étrangère, les recherches interculturelles, incluant l'anthropologie culturelle, et la traductologie. Dans un premier temps, je décrirai sa perspective du traducteur/interprète idéal comme expert culturel. Ce dernier agit comme « mini-ethnologue ». Je tenterai d'aller plus loin que Göhring en liant sa pensée avec le concept de l'ethnologue critique en tant que modèle pour l'interprète communautaire professionnel. Je voudrais démontrer dans cette discussion théorique comment une synthèse du cadre proposé par Göhring peut être combinée avec des théories anthropologiques actuelles, non seulement dans le domaine communautaire, mais aussi en général. En plus des aspects concernant la politique de la traduction et de l'interprétation, je voudrai souligner que la révision des rôles de l'interprète doit également influencer la pédagogie et les recherches de la traduction et de l'interprétation.
Ce document est protégé par la loi sur le droit d'auteur. L'utilisation des services d'Érudit (y compris la reproduction) est assujettie à sa politique d'utilisation que vous pouvez consulter en ligne.

https://apropos.erudit.org/fr/usagers/politique-dutilisation/ 


\title{
Moving In-Between: \\ The Interpreter as Ethnographer and the Interpreting-Researcher as Anthropologist
}

\author{
ŞEBNEM BAHADIR \\ Boğaziçi University, Istanbul, Turkey \\ sebnembahadir@turk.net
}

\section{RÉSUMÉ}

Dans les domaines du droit, de la santé et des services sociaux, l'interprète communautaire se voit confronté à des problèmes éthiques particulièrement délicats. Tout en recherchant un cadre théorique adéquat pouvant expliquer les rôles sociaux et les identités culturelles de l'interprétation communautaire, j'ai entrepris une re-lecture du sociologue et interprète de conférence allemand Heinz Göhring. Ses articles se situent entre les disciplines allemandes comme langue étrangère, les recherches interculturelles, incluant l'anthropologie culturelle, et la traductologie. Dans un premier temps, je décrirai sa perspective du traducteur/interprète idéal comme expert culturel. Ce dernier agit comme «mini-ethnologue». Je tenterai d'aller plus loin que Göhring en liant sa pensée avec le concept de l'ethnologue critique en tant que modèle pour l'interprète communautaire professionnel. Je voudrais démontrer dans cette discussion théorique comment une synthèse du cadre proposé par Göhring peut être combinée avec des théories anthropologiques actuelles, non seulement dans le domaine communautaire, mais aussi en général. En plus des aspects concernant la politique de la traduction et de l'interprétation, je voudrai souligner que la révision des rôles de l'interprète doit également influencer la pédagogie et les recherches de la traduction et de l'interprétation.

\section{ABSTRACT}

My starting point in this article is the community interpreter who works in social, medical and legal settings, under specific conditions, confronting very delicate ethical problems. In search of a theoretical framework that accounts for the social roles and cultural identities of the community interpreter I began to re-read the German anthropologist and conference interpreter Heinz Göhring. His articles can be positioned between German Studies ('Deutsch als Fremdsprache'), intercultural communication studies (including cultural anthropology) and translation studies. I start out with his view of an ideal translator/ interpreter as cultural expert acting like a "mini-ethnographer" and try to go beyond Göhring by connecting his ideas to the concept of the critical ethnographer as model for a professional community interpreter. In this theoretical discussion I want to show how a synthesis of the framework proposed by Göhring and recent anthropological theories can be used for a new professional profile of the interpreter, not only in community settings but in general. Besides aspects concerning translation/ interpreting politics, I wish to foreground that a re-thinking of interpreter roles would/ should also affect translation/ interpreting pedagogy and research.

\section{MOTS-CLÉS/KEYWORDS}

anthropology, Göhring, interpreter-ethnographer, interpreting-researcher 


\section{Making/Leaving the Interpreter Visible and Complicated}

I am writing as a person with at least two identities: as interpreter and interpretingresearcher. These two professional identities, if you look closely at them, consist of a multitude of social and cultural roles, positions and attitudes. ${ }^{1}$ At the beginning of my article is the word ' $\mathrm{I}$.' This ' $\mathrm{I}$ ' as interpreter and interpreting-researcher is what I want to write about. I will neither end up with anecdotal narrations nor lose myself in the philosophical and political dimensions of identity matters. The 'I' here and now is just an example. It is not my aim to reach clear-cut definitions or any illuminating presentation of its constituents. It is rather from the opposite side that I will try to approach the identity of the interpreter/ interpreting-researcher. I want to foreground the complexities and complications in the roles and identities by dwelling upon the multi-layered positions of the interpreter/ interpreting-researcher within the very specific communication situations they respectively experience.

I wish to draw a parallel with the identity and position of the ethnographer/ anthropologist. My point of departure here is a re-reading of Heinz Göhring's concept of the interpreter as an ethnographer engaged in fieldwork, especially with respect to participant observation and interviews with 'informants' $(1977 ; 1980){ }^{2}$ My title comes from this analogy: Ammann (1995:43) notes Göhring's use of the term Ethnologe in diminutive form (Mini-Ethnologe) when talking about what he expects from a translator. Within this re-reading I would like to work with a second level of analogy between the interpreting-researcher and the anthropologist. This idea is based on the assumption that the anthropologist is the categorizing and theorizing part of the ethnographer, trying not only to grasp cultures but also to (re)present them in writing, thus trying to 'translate' them for a special audience. ${ }^{3}$ Göhring's professional 'cultural mediators' (Kulturmittler) benefit from practical methods like ethnographic fieldwork and from the theoretical frameworks of sociology and cultural and social anthropology (1976a, 1976b, 1977, 1980, 1998). As conscious practitioners they would be convinced of cultural relativism. Within the framework of their professional ethics they would try hard to reflect this relativistic, egalitarian and anti-ethnocentric attitude in their actions by striving for the highest possible detachment and objectivity. Vermeer took up Göhring's definition of culture and developed it further for his Skopos Theory in which certain foundations for a profile of the professional translator are laid (cf. for example Vermeer 1986:178-196). Theorists of the German functional approach basing their work on Vermeer's Skopos theory, like Ammann, Nord and Witte, followed Vermeer and made use of Göhring's definition of culture, of cultural competence and of cultural roles/identities. However, Göhring's comparison between the translator/interpreter and the ethnographer has not been dwelt upon extensively. It has been noted now and then, but in passing. For me this analogy is like a programme, a framework for both a pedagogy for translator/ interpreter training and for a professional ethics.

My reading of Göhring leads both the interpreter/ethnographer and the interpreting-researcher/anthropologist to the critical ethnographer's crise de conscience. This crisis is caused by a questioning of identity and position within mediating activities, against the background of the changing political and ideological structures in the countries traditionally preferred by anthropologists. The result of this disorientation 
is the acceptance of various perspectives, which, in my analogy, applies to the work of the interpreting-researcher as well as to the interpreter.

Nowadays cultural, social and professional identities are multiple and subject to hybridization (cf. Bhabha 1994a, 1994b, 1996; Hall 1996a, 1996b; Bauman 1997; even much earlier Goffman 1959). Since this is one of the theoretical pillars my paper is built on, the borderline between reflections on the social, cultural, political and ethical positions of the interpreter on the one hand and the interpreting-researcher on the other becomes dynamic and flexible as well. Following a way of looking at the world that can be related to thinkers generally known as poststructuralist or deconstructionist, I would like to try to step out of the sphere where transparency, invisibility, neutrality, and along with these ideals, a kind of 'dehumanization' represent the professional standards for both (community) interpreting and research on (community) interpreting. ${ }^{4}$ Similar deliberations and limitations determine the activities of both interpreting-researcher and interpreter. The interpreting-researcher is caught in the Geertzian dilemma between the emic and the etic perspective (cf. Geertz 1973) etic meaning looking from outside, without involvement into the culture to be investigated and emic looking from within, as an insider. ${ }^{5}$ The interpreting-researcher is steadily moving from involvement to detachment and back. This involves a pondering how to observe, to comprehend, to describe (i.e. name), to evaluate and then to mediate (i.e. interpret) as an 'I' (i.e. a person-in-cultures ${ }^{6}$ ), provisionally designated researcher, the Others (i.e. persons-in-cultures), provisionally named 'research objects.' Interpreters, too, face the question of whether and how they have the capacity/ right/ responsibility to observe, to comprehend, to describe (i.e. name), to evaluate and then to mediate (i.e. interpret) as an 'I' (i.e. a person-in-cultures), provisionally designated interpreter, (between) the Others (i.e. persons-in-cultures), provisionally named clients, patients, migrants, doctors, lawyers, social workers, psychiatrists, etc. In current discussions on the social and political status and the professional roles of the community interpreter, the ideal of neutrality and objectivity as the best way toward an ethics of this profession is constantly repeated. My reflections are based on a resistance to one-dimensional and simplifying professional standards with a tendency to neutralize and assimilate interpreting activities into a transparent, totally analyzable and predictable, strictly defined shape.

Within the multifarious (semi)theoretical (and often anecdotal) literature on interpreting in social, medical and legal settings some empirical studies show clearly that in interpreting as a special form of intercultural communication the interpreters by their very presence communicate 'something' and interact with the other(s). I would like to mention a less known article by two medical doctors on their therapies with Turkish patients assisted by interpreters: Knoll \& Röder (1988) refer to Vermeer (1985) when they defend the view that it is always the cultural and situational context which is translated. Any conversation, whether between two or three parties, is based on a pragmatic basis of common action, not 'real' comprehension. All the persons in interaction create the communication situation, what then looks as if they would understand each other. Whenever they hear, see, perceive something, they re-shape it in order to be able to comprehend. The authors support Vermeer's demand for an interculturally interpretive translation of all action that takes place during the translation situation. Thus a so-called falsification of any information, whether verbal or nonverbal, will inevitably happen in interpreted interaction as in any other 
communication (1988:114). This conviction reminds me of Watzlawick's assumption, to which Göhring (1998) refers, that we cannot not communicate, i.e. that we communicate by just being and behaving (Watzlawick et al. 1967). Göhring takes this concept of communication as the basis for intercultural communication. Wadensjö also tries to illustrate with her case studies that trying to be as much a "nonperson" as possible while interpreting is not a guarantee for good or better interpreting (cf. especially 1998b). However, the role of the interpreter as a third party within this communication context is not widely accepted. The 'dehumanizing' ideal of the interpreter as invisible and/or transparent agent (cf. "pane of glass," Schweda Nicholson 1994:84) underlies many codes of ethics, especially if they are designed for legal contexts. In most countries of immigration, the judicial institutions seem to put a major emphasis on the professionalization of interpreting activities. These codes of ethics, then, often serve as a model for the social and medical settings. Yet merely adopting or adapting these standards of legal interpreting without critical reflection is not an in-depth solution for a professional ethics that is intertwined with the applied field. It is striking that in some studies on court interpreting the divergence between theory and practice is depicted as a very controversial subject (cf. Morris 1995; Barsky 1996). I will not go into the details of my reading and evaluation of the literature on community interpreting here. I would rather depict a special view of the roles and identities of a professional (community) interpreter by building up a theoretical framework in which I am going to position the issue of professional identity for (community) interpreters.

I would like to argue that a re-evaluation of Göhring's demand for the foreign language/culture learner as well as teacher, for the translator and interpreter, in short, for the expert in intercultural communication, to be equipped with the methodological resources of cultural anthropology, ethnography, and sociology (1998:114) provides us with a very sound and practical basis on which we could develop the profile of a professional (community) interpreter. A step further toward the ethos of the postcolonial, critical ethnographer leads us, then, to a redefinition of freedom, responsibility and visibility as vital elements of a professional ethics for interpreters.

My aim here is not to repeat what has been discussed for some time within the framework of critical approaches to translation and interpreting as activities that are not as innocent, transparent and apolitical as illusory ideals would like us to believe. ${ }^{7}$ What I want to concentrate upon is the need for a flexible, dynamic ethics that appeals to a (self)critical and self-reflexive professional community interpreter. These features could and should be demanded for a professional code of ethics for interpreters and translators in general. But in here I will position my reflections, based on analogies with, and inspired by the figure of the critical ethnographer, within the special context of community interpreting.

\section{The interpreter-ethnographer 'immersing' in cultures}

The ethnographer may be seen as immersing in culture(s) by way of fieldwork, theorizing and categorizing on the basis of data collected through extensive participant observation and interviews with 'informants.' This is a model for the ideal cultural mediator in Göhring's writings. His main concern is with the training and consciousness-raising of foreign language/culture learners and teachers as well as 
translators, who will act as intercultural communication experts. The translator/ interpreter whom Göhring has in mind should be trained to mediate between cultures in real life situations, i.e. should obtain academic training based not so much on linguistic exercises in a vacuum-like classroom situation but shaped by an interactionist approach. Within the framework of seminars aiming at experiential learning rather than abstract knowledge acquired from books and lectures, simulations and role plays are foregrounded. Major emphasis is put on close contacts and exchanges with members of the cultures concerned in multicultural working groups and during longer stays in those cultures. In this context Göhring proposes and applies in his teaching praxis the idea of Tandem-Lehre or 'tandem-learning,' a type of training based on the principle of consciousness-raising through 'intercultural exchange' that can only be realized in inter-/multicultural group settings (1977:175). As a result the translator should know how to act in culture(s) according to and/or against the norms, rules, conventions, etc. (1980:73). Göhring describes the translator as a professional who acts interculturally rather than merely possesses the abstract knowledge of this acting. In this context, the nonverbal and behavioural aspects of this (en)acting play a very important role (1978:11-12). First, while 'learning' a culture and later on when communicating with its members, the translator should approach the members of this culture with the tools of cultural relativism as a remedy against ethnocentrism and prejudices. Ethnocentrism here describes the 'human' tendency to take their own culture as the measure and point of reference while mediating between two cultures. As to prejudices, they include both positive and negative ones on at least three levels: prejudices about their own culture, about the Other, about what one thinks the Other thinks of one's own culture. For Witte (2000:67) these three levels of 'images' determine any communication with and perception of the Other within and between cultures, and must necessarily be taken into consideration when reflecting upon the constituents of the professional translator's cultural competence. ${ }^{8}$ Contrastive analyses through observations of and interactions with persons in other cultures, and continuous reflections on one's own culture-specific attitudes and behaviour will help the student (and later on the professional) to master culture shock situations, to embrace the foreign, to put too hasty ethnocentric judgements into brackets - and all this with the aim to have access to the culture from 'within' (Göhring 1976c:80-81). Göhring defends the view that both the theoretical analysis and the experience of culture shock lead the foreign language/translation and interpreting students to develop an awareness for culture-specific attitudes, norms, beliefs, actions, etc., to reflect upon their own culturally bound situation and to 'open' themselves for other cultures. Culture shock is thus taken as a "transitional experience" (cf. Adler 1974/1994) disorienting the students by subverting all that is 'normal' and taken-for-granted around them (not only while staying in a foreign culture, but also in the classroom through role plays and simulations). Cultural relativism then can be erected upon this loss of the one and only secure system of orientation (1980:78-83; 1976b:185; 1976c:82-85). Göhring included at a very early stage of the research on culture shock the insights of its non-pathological handling, especially in the writings of Adler, into his reflections on the training of translators/ interpreters. ${ }^{9}$ His belief in the possibility of an impartial, rational and enlightened way of encountering cultures is to be questioned below, when the empirically-oriented, scientific, liberal interpreterethnographer experiences a severe crisis of representation. For the moment, suffice 
to note that "the relativist effort which often claimed to substitute a 'humanist' perspective for the scientific one or to juxtapose them, sought [...] the faithful representation of the Other's 'culture,' in its own unique terms" (Dwyer 1979:207).

Thus Göhring defends the validity of the scientific project of the academic fieldworker-ethnographer-interpreter who was created within the Anglo-American tradition of social and cultural anthropology. This scientific ethnography, with its empirical descriptions and eagerness to arrive at explanations and theories in its search for generalizable functions of cultural units and entities (Dwyer 1979:207208), is at the same time "a pedagogical, ethical undertaking" (Clifford 1986:102103). As a counter-movement to $19^{\text {th }}$-century 'armchair ethnology', ethnography emerged in the 1920s and 1930s as an academic discipline with methods of its own. The 'forefathers' of anthropology developed their theories of universal laws for the evolution of human cultures on the basis of secondhand data like travel accounts, records by colonial administrators and missionaries. Ethnographers, however, introduced the collection of data through fieldwork and participant observation during longer stays in the culture to be observed, ending up with descriptive accounts of cultures in an analytical, rather detached language. Their aim was to work out typologies of cultural patterns and to wipe out any trace of investigator's personality. Cultural relativism in this period was, especially for American anthropologists, more than just a method; it was an ideology that also pervaded other areas of the social sciences. This doctrine experienced a revival after World War II (Marcus \& Fischer 1986:17-20) and was not only influential upon the postwar orientation of the social sciences in American contexts but was also a kind of 'salvage ideology' after the devastating experience of Nazi ideology in the social sciences in Germany. Göhring can be positioned in this postwar paradigm of German 'liberalized' (if not 'AngloAmericanized') empirical, positivist sociology and anthropology. He compares the process of learning how to behave and act in a foreign culture with socialization (1976a:146; 1977:11). The scientific fieldworkers' traditional positioning also tells us that the acquisition of cultural competence demands a second socialization. This concept of a 'childlike' initiation into a new culture is clearly ascribed both to the ethnographer-in-fieldwork and the learner of foreign languages/ cultures, by which Göhring means translators-to-be. The main dynamic of the interpreter's/ethnographer's ethical undertaking is getting to know the new culture by means of complex and multiple learning processes. 'Learning the culture' engenders situations of appropriating and being appropriated (1976c:81). This attitude is described by Dwyer ironically and/or in disillusionment as "metaphors of 'discovery" within the commentary on fieldwork "where the focus is on the skills and tools the fieldworker will have gained which finally allow access to the - until then - unattainable Other" (1979:209). Göhring's ethnographer-interpreter acquires sensitivity and intercultural communication competence first through participant observation, then active participation in the culture. Witte claims that in Göhring's definition of cultural competence the aspect of 'everyday cultural competence' (Alltagskompetenz) is included, while the professional component is not very clear because he talks mostly of members of one's own or of the other culture and not expressedly of professionals (2000:53). I do not think Göhring neglects this vital aspect, because his addressee is no doubt the language/ culture learner (who is going to make use of language and culture competence in professional life), the language/culture teacher, the student of translation and 
interpretation (most explicitly expressed in Göhring 1980: 70). All of Göhring's writings emerged out of his experiences with and reflections upon teaching cultural anthropology and sociology to students of translation and/or interpreting, and were intended as contributions for the improvement of the curriculum.

Göhring's reflections on the academic training and professional identity of the ethnographer-interpreter lead us to the following ideal picture: the interpreter should be trained as an intercultural communication expert whose profession evolves around cultures and communication between persons belonging to these cultures. Göhring suggests that culture should be taken as anything that translators and interpreters as researchers of culture and experts for intercultural communication should know and feel concerning their source and target cultures. He adapts the definition of culture by the cultural anthropologist Goodenough (1964) for this purpose. This 'knowledge' should enable them to judge how persons in these cultures act not only in conformity with the different roles they are expected to take on, but also how and when persons transgress these role expectations. As a next step the translators/ interpreters should have attained the capacity not only to understand these roles but also to perform them, if required. And this playing of social roles should include both conformity and transgression in the latter case the person should know how to bear the consequences of breaking social rules. The third dimension of Göhring's cultural competence is the domain of perception, thinking and emotions: to feel, see, think, etc. like a 'native' (Einheimischer in German) is the highest level of this ideal immersion in a culture (cf. 1980:73-76; 1998:112-113). Taking on the roles and rituals within the studied culture by digging deep enough in the social structures, by trying to become a member of that culture is a traditional goal of fieldwork. This attitude at some point produces a clash with the theorizing academic fieldworkers' project (cf. Clifford 1988:29-31). In surrealist ethnography, to use Clifford's term, best represented by Leiris who is very aware of running after a phantom, a construction, a dream called Africa, (cf. Albers 1999) this "hopeless attempt to 'go native"' (Dwyer 1979:217) is fundamentally shaken. But on the level of a model for intercultural communication competence Göhring still seems to trust in this method:

Every culture then teaches me that I could have been living that way if I were born into this culture. "Living that way" means looking, smelling, tasting, thinking, perceiving, speaking, feeling, moving, loving, hating, quarreling and making peace, judging as beautiful or ugly, as good or bad, in short, behaving as any native, and taking all this as granted, as 'natural' as they do. (1980:72; my translation)

He uses the German word for native, Einheimischer, more in the sense of 'a member of a society/ community/ culture.' Witte very aptly draws attention to the fact that Göhring while consciously stressing the foreigner's perspective does not intend to use Einheimischer in its narrow sense. He does not exclude those members of a society or culture not 'native' but 'nativized,' like for example second-generation immigrants (Witte 2000:51, footnote 66).

What is very important in this respect is that, for Göhring 'immersion' in the other culture always implies the drawing of conclusions for one's own culture. The development of a sharpened awareness of one's own culture is even a prerequisite for knowledge of the other culture; or let's say, these two cognitive and affective processes 
are complementary in Göhring's writings. In his sketch of a training programme for foreign language/translation and interpreting students, the first item is a seminar on monocultural interaction and consciousness-raising. He provocatively calls this training Interaktionelle 'Leutekunde,' a seminar, in which the question, how to interact with the people of a culture, would be foregrounded. This designation was concocted by Göhring in opposition to the outdated Landeskunde which only meant written facts and data about a culture, delivered to the students in a top-down-process (1976a:148, 151-152; cf. also 1976b:190-193; 1977:171-176).

This double move, i.e. acquiring a more sensitive view of one's original culture by means of entering a foreign culture, even understanding things better after a period of alienation, is a method ethnographers use in order to somehow 'instrumentalize' accounts of the foreign for first reflecting upon, then criticizing their own culture. Geertz, in his discussion of Ruth Benedict's work, calls this technique "the juxtaposition of the all-too-familiar and the wildly exotic in such a way that they change places" (1988:106). Clifford illustrates how ethnographers like Bronislaw Malinowski, Margeret Mead and Marcel Griaule, as a new breed of fieldworkers, adopt cultural relativism, scientific explanation, generalization and theorization as professional standards for their commentaries. But at the same time there is a tendency Clifford calls "ethnographic surrealism" (1988:12), as, for instance, in the very self-reflexive and critical, if not poetic literature by Michel Leiris. Clifford's re-reading of him as surrealist ethnographer demonstrates how Leiris views culture as artefact, how he constructs culture by writing about it. In his writings on the fieldwork he carried out, he seems to be in search of himself and his society rather than the foreign culture (1985a:165-174; cf. also Albers 1999; Heinrichs 1985).

Within Göhring's reflections on culture, the awareness of the multitude of different layers of identities and roles a person plays has a privileged position. Cultural competence, whether concerning one's 'own' or the 'foreign,' always consists of mechanisms to handle various dimensions of culture (subculture, regional culture, culture of a social group, 'ideo-culture, cf. 1980:75-76). When discussing requirements and training methods for intercultural communication competence, Göhring often dwells upon bi-/multicultural identities. Intercultural communication means taking on roles, switching between a variety of identities in different culture-specific situations. In a 1998 article Göhring mentions that people nowadays often construct their individual repertoire of behaviour out of two or more cultural systems. For many people it is no longer that easy to draw a clear line between original and target cultures (1998:113). ${ }^{10}$ Due to these multi-layered cultural roles, a critical gaze and painstaking examination are required from the interpreter-ethnographer: first, when studying the cultures, then, when working with/in them. On the one hand this selfreflexive and relativistic approach questioning all cultural elements that are taken for granted is presented as a humanistic project with the ideal of overcoming ethnocentrism and striving for a global transcultural solidarity (1977:176). But there is also another aspect to this relativistic viewpoint in Göhring's writings which expresses that communication is always culture-specific, that no perception of and reflection on something can be impartial. Göhring postulates that translators/interpreters perform the function of an intercultural mediator by questioning given aspects in any culture and trying to break free of their culturally bound position (1980:71). He does not openly speak of the impossibility of mediating between two or more cultures 
without the influence of one's own culture(s). It is his pedagogical and ethical aim to find a remedy for the ethnocentric attitude that is foregrounded in his works.

But still I think there is a path leading to the critical ethnographer's crise de conscience in his emphasis on making conscious all that goes on in us subconsciously (under the heading of ethnocentrism). Göhring's recognition of the multitude of roles and identities a person enacts while communicating interculturally is one factor opening up a way to a complex kind of ethics. The second one is his concern with the subconscious dynamics of ethnocentrism. In a sentence, which, at first sight seems to be mentioned in passing, he states that the fieldworker has/adopts/appropriates a culture, but at the same time is appropriated/shaped by it: "Der Feldforscher hat nicht nur seine Zielkultur, er wird auch von ihr gehabt” (1977:11). Ethnographers are captured not only by the original culture, thus bringing an ethnocentric attitude with them to the place of fieldwork, but are also 'occupied' by the target culture, as soon as they reach a state of 'biculturality.' At that point a second type of ethnocentrism emerges. Having access to and becoming socialized in a second culture in the course of fieldwork means not only that the ethnographer develops a certain cultural competence, i.e. learns how to behave, think, feel, etc. in that culture. The appropriation process here is bidirectional: As soon as they 'own' the target culture (just like in the case of their first culture), they are manipulated and determined in their behaviour and way of thinking by this new culture as well. As a consequence the ethnographer has to cope with multiple patterns of perception and evaluation, even with flexible loyalities.

Göhring often mentions Adler's ideal type of 'multicultural man' in his writings. This idea of multiple cultural influences again reminds us of him. Although Adler can be criticized for describing "multicultural man" as "timeless" and "universal" (1974/1994:242, 243), his displaced multicultural man mirrors in some aspects the (post)modern interpreter/ ethnographer:

The multicultural person, therefore, is not simply the person who is sensitive to many different cultures. Rather, he is a person who is always in the process of becoming a part of and apart from a given cultural context. He is very much a formative being, resilient, changing, and evolutionary. He has no permanent cultural character but neither is free from the influences of culture. (Adler 1994:249)

Göhring's acceptance that the models of perception and categorization in fieldwork, and later in writing about it, are always influenced by the target and/or source cultures can be seen as the link to the postcolonial ethnographers who have become aware of their partiality and visibility. As a culture-bound and ethnocentric person, their writing symbolizes the attempt to get a grip on the disintegration of the ethnographic project which is to grasp the cultures as scientific and 'real' objects of research.

\section{The critical interpreter-ethnographer immersing in 'in-between-cultures'}

After the breakdown of the colonial world, traditional forms of ethnology/ethnography/ anthropology born out of the orientalizing and exoticizing drive of colonialism lost the secure ground of hegemonic structure under their feet. Up to this subversive moment the ethnographer was generally accepted to have the capacity of switching, 
by means of empirical methods, in a neutral, objective manner, from the insider's perspective to the outsider's gaze and vice versa. Major ethical dilemmas arising from the meta-position of the 'cultural expert' were mostly suppressed until anthropology's crise de conscience started in the 1930s, mainly in France with Michel Leiris and other 'surrealist' ethnographers (cf. Clifford 1988:12, 21-54). This trend took even more radical forms in the 1960s and 1970s, within the framework of a general crisis of methodology in the social sciences (cf. Marcus \& Fischer 1986:33-44). The ethnographic crisis reflects the struggle of 'Western-centric' science becoming aware of the "vulnerability" (Dwyer 1979:205) of its social scientific project in a world with more and more complicated and multidimensional political and ideological conditions. The discipline's domesticating drive is contested, especially under the influence of deconstruction, poststructuralism and postcolonialism. Derrida explicitly mentions ethnology as an example of a European science which, in resisting the restrictions of ethnocentrism, cannot prevent shaping its scientific discourse with ethnocentric tools and concepts:

And it is primarily a European science employing traditional concepts, however it may struggle against them. Consequently, whether he wants or not - and this does not depend upon a decision on his part - the ethnologist accepts into his discourse then premises of ethnocentrism at the very moment he denounces them. This necessity is irreducible; it is not a historical contingency. We ought to consider all its implications very carefully. (1990: 282)

Referring to Derrida, Dwyer says that "anthropology, even where it contested aspects of this historical process, was inevitably embarked upon Western society's project" (1979:206). Many critical ethnographers shifted their attention from 'exotic' and 'distant' cultures, first to their own cultural identities and ideological positions, then to their ways of constructing foreign cultures as distant and 'other' through their ethnographic gaze. Anthropologists like Claude Lévi-Strauss expressed sadness for the fragmentation of human history and melancholic recognition of the impossibility of salvation for cultural systems untouched by Western civilization (cf. also Marcus 1986; Clifford 1988:14-15):

The world began without man and will end without him. The institutions, morals and customs that I shall have spent my life noting down and trying to understand are the transient efflorescence of a creation in relation to which they have no meaning, except perhaps that of allowing mankind to play its part in creation. But far from this part according man an independent position, or his endeavours - even if doomed to failure - being opposed to universal decline, he himself appears as perhaps the most effective agent working towards the disintegration of the original order of things and hurrying on powerfully organized matter towards ever greater inertia, an inertia which one day will be final (1974:413).

Fieldworkers like Michel Leiris, writing on the fringe of ethnography, show how the ethnographer alienates both the original and the target culture (Albers 1999:197). Leiris's ethnographic records, manuals, accounts, commentaries, diaries, letters, in short the totality of his writings during and after his fieldwork in North Africa appear as a foretaste of the postcolonial need for subversion, transgression and parody as tools in the ethnographic 'enactment' of cultures (cf. Clifford 1988:131). There cannot be a person who is 'only' a scientist, says Leiris; sociopolitical interests 
always determine the situation when a European ethnographer does research in a colonized territory. There can be no impartiality and objectivity in the fieldwork situation. Power struggles and the domestication of the alien play an inescapably major role. Ethnographers as intercultural agents thus have to 'position' themselves. Leiris clearly demands that the ethnographer take a stance on the political conditions determining the status of colonizing and colonized cultures (1985/1950:54-56).

This is exactly the point at which my re-reading of Göhring's concept of the interpreter-ethnographer needs. to be extended. The interpreter-ethnographer today has to take a stance and develop a consciousness for the political and ethical dilemma between the domesticating of the Other and leaving the Other as foreign.

Nowadays community interpreting has become somewhat fashionable. International migration, multicultural societies, bicultural identities have become catchwords just like globalization. Practitioners, trainers and service providers in the domain of community interpreting are in search of a professional profile. They reflect a tendency to some kind of inferiority complex when looking at (or even upwards to) the profession of the conference interpreter. Since the actually experienced interpreting situation is so complex and loaded with ethical dilemmas on different levels, there is a striving for best possible abstraction of the activity and for simplification of the professional profile. In contrast to this tendency, I expect from a code of ethics for professional community (and any other kinds of) interpreters to 'restore' the difficulty and the complexity of interpreting, to foreground the necessity of an awareness of the 'vulnerability' of the project of translation/interpretation (cf. also Wolf 1997:131-132). ${ }^{11}$ The point of departure for a professional profile should be the insight that community interpreting is a highly complex ethical and political activity. The ethnographer-interpreter has to experience what interpreting for and between cultures involves, what risks and benefits are at stake, which and how much responsibility and freedom has to be taken on. Of course, this experience or wisdom can also grow out of very personal 'culture shocks' in the course of interpreting activities. The competence can be acquired when interpreters develop, in a sometimes very long-lasting process, a certain awareness, and, to use Toury's designation, something like a 'native translator's self-reflexiveness (cf. Toury 1986; also Bahadır 1998). No doubt, there are quite a few very skilled, very conscious, in the meantime very professional autodidact-interpreters. But as researcher and trainer in the academic field, I cannot be satisfied with this 'natural-selection-type' of awareness-building. The more professional way to handle this necessity is preferably by way of a sound and conscious experiential and critical training, within a programme for which Göhring's ideas can be made use of. Interpreters should be made aware that seeing, reading, writing (i.e. translating) the other culture as similar to mine means incorporating it into 'my world,' in order to make it comprehensible and thus 'digestible' (cf. Fichte 1988; Weinberg 1999). They should recognize that acknowledging the strangeness of the other culture only ideally (and ideologically) prevents assimilation - this strategy also assimilates and at the same time engenders some kind of indulgence in a 'salvage ideology' of cultural relativism and anti-ethnocentrism. At the bottom of this attitude very often lies dissatisfaction with one's own culture, the longing for the Other, in order to escape one's own, much criticized culture. Thus translating the other (Other's) culture as foreign again serves the needs. 'I,' as the interpreter, have within the context of 'my', i.e. the target culture. Leaving an utterance, a text, a culture 
foreign then, if pushed to its extremes in the Leiris'ian sense, is a 'making-my-own' of the Other as the Other. If 'I' leave the Other strange and different 'I' always do this from 'my' culture(s)-bound viewpoint, satisfying 'my' culture(s)-specific needs. and purposes. This paradox is a burning issue in interpreting between cultures: translation/interpreting is never carried out on equal terms.

This is not a new insight. The complication becomes pervasive when this double move is not taken as an oppositional pair but as a dynamic working within translation/interpreting all the time, in a dialogic way, overlapping to differing degrees and with different intensity. Interpreting has always implied imbalance in power, and multiplicity in meaning. This double move is also very much related to applied practice, to the 'fieldwork' of community interpreting. Again I will have recourse to Leiris' ethnographic texts reflecting a borderline phenomenon on which both the original and the target cultures are 'staged' (Albers 1999:220). Interpreting in the sense of professional intercultural communication can also be seen as a 'staging' of both cultures plus a third one. Interpreters, too, are engaged in a borderline activity, producing other cultures against the background of their own cultures, and creating a new space, a third culture, "something like culture's 'in-between,"” as Bhabha (1996:54) would put it.

An evaluation of the debates especially in the 1980s (cf. Clifford \& Marcus 1986) on ethical and political questions in ethnographic representation which lead to a drastic shift in the (self)image of the ethnographer is very rewarding for the discussion of the professional roles of the (community) interpreter. These questions include: Under what circumstances does the ethnographer have the right/authority/duty to speak for/interpret the Other? What power relations influence the acts of interpretation and representation? How does the ethnographer as a person-in-culture(s) shape the outcome of the observations? And finally, how are other cultures enacted and created by the ethnographic gaze? These constraints also apply to the situation of the community interpreter as a cultural expert comparable to the ethnographer. On the one hand there is the expectation of being impartial and factual, of looking as an outsider but still being an insider. On the other, this idealization clashes with the often unconsciously experienced situation in which the interpreter takes part in the communication as a third party, thus representing and mediating between the cultures not as an exclusive insider or complete outsider but as a third party in-between.

Within this line of thought I would like to conclude with the conviction that it is necessary to take a closer look at the 'fieldwork' of the community interpreter. The actually lived experiences show us a path out of endless (semi)theoretical discussions in a prescriptive vacuum. Like the fieldworkers who, within a revision of interpretive anthropology, start to write down their reflections on the ethnographic research process, the commentaries and evaluations of interpreters should be taken into account more seriously. These ethnographic accounts are critical of the methods of (re)presenting their 'objects/subjects' of research; they are very much aware of the influences of both source and target cultures on writing. With them, a period of selfreflexive experimentation as to the style of 'translating cultures' has been introduced (Marcus \& Fischer 1986:42-44). Such an experimental approach would make us reconsider the multidimensional implications of interpreting between cultures, and thus redefine ethical constraints and deliberations. Discussions of the ethnographer's taking on responsibility through conscious visibility provides us with a parallel situation. 
We should take these discussions as a point of departure for reflecting on the (community) interpreter's position in order to arrive at a professional profile for interpreters that gives them the chance to speak about and with other cultures as self-reflexive and (self-)critical experts for intercultural communication with voices of their own.

\section{Epilogue}

So I finish my paper by returning to the beginning: the project/prospect to make both the interpreter and the interpreting-researcher visible. I have not discussed actual critical instances (community) interpreters experience. Ethical dilemmas arising from the third position in-between two cultures, the so-called foreign and the so-called own, have been pinpointed but not illustrated. The professional role and the social status of this profession is to be worked out against the background of cases explicating this in-between position. For this purpose, the accounts and reports of interpreters should also be taken into consideration. The evaluation of recorded instances of actual interpreter-mediated talk is no doubt of importance. But regarded from the perspective of critical anthropologists, this 'gaze from the outside' is not necessarily more 'objective,' thus reliable and trustworthy than the very personal and subjective reports of 'involved' interpreters. Interpreting-researchers are involved in one way or the other, too. Their evaluation of recorded material just represents possible 'readings' of it. The moment of experimental and self-reflexive methodology should also be extended to the activities of the interpreting-researcher. But before going over to application, any method is to be worked out within the framework of theoretical discussion. Otherwise cases and examples remain in the void. Here my aim was to lay some kind of a theoretical foundation for a consciousness-raising as to the hybrid cultural and social roles interpreters play while performing their activities. Re-reading Göhring and trying to establish a connection between his views and recent developments in cultural anthropology and ethnography served two purposes: On the one hand, I wanted to take Göhring's translators/interpreters as Mini-Ethnologen to the margins of their cultural identities and professional competence. On the other, it was a modest attempt to highlight that Göhring's anthropological reflections and those going beyond him should get a place within the field of translation and interpreting studies.

\section{NOTES}

1. Many further specifications could be made, like: of 'Germany-Turkish' origin (as a literal translation of the German designation Deutschland-Türkisch); of Islamic family background; socialized in German (Christian) schools and institutions; at the moment living, teaching and doing research in Germany and Turkey, etc. All these dimensions are implicit but will not be discussed in detail here.

2. Heinz Göhring was Professor of Intercultural Communication Studies between 1971 and 1995 at the Faculty of Applied Linguistics and Cultural Studies of Johannes Gutenberg University Mainz/ Germany. His position as cultural anthropologist (in German 'Kultursoziologe') and at the same time conference interpreter was extraordinary at a faculty where students are trained as translators and interpreters, and the academic staff was (and still is) mainly composed of linguists and specialists in literary studies.

3. Ethnographic fieldwork and anthropological writing based on it are often described as 'cultural translation' (cf. Asad 1986) or 'translation of cultures' (cf. Rosaldo 1993), especially by critical anthropologists engaged in the project of re-reading anthropology as cultural critique (cf. also Marcus \& Fischer 1986; Geertz 1988; Clifford 1988, 1997). In translation studies theorists like Niranjana 
(1992) and Venuti (1992) look at developments in anthropology and ethnography within the framework of (post)colonialism. Wolf (1997) also points to parallels between cultural anthropology and translation with regard to power relations and the assertion of power within the translation process. Her article ends with a plea for "more intensive interdisciplinary collaboration" (1997:132).

4. The adjective community is in brackets because the reductionist ethical standards postulated for all sorts of interpreting most probably have their origin in definitions of professional behaviour in simultaneous (conference) interpreting (cf. Diriker 1999, 2001).

5. Marcus and Fischer show that Geertz tries to revise this traditional distinction which was borrowed from linguistics. This discipline had served as a model for approaches such as cognitive anthropology, structural anthropology and, supported by hermeneutics and semiotics, Geertz's interpretive anthropology. As there cannot be a purely etic (i.e. culture-free) way of interpretation, Geertz modifies the absolutism of the terms by introducing "experience-near" and "experience-far" (1986:28, 30, footnote 6).

6. Cf. Göhring's views on the human 'ability to acquire/have cultures' ('kulturenfähig') (1980) and Adler's reflections upon being culturally bound (1974/1994). For Witte (2000) this 'ability to acquire cultures,' interdependent with the constraint that any human action is culturally bound, is the basis for her discussion of 'Kulturkompetenz' as central competence of a professional translator. In her dissertation she then goes on reflecting upon how to work out didactic concepts for the training of translators with a professional cultural competence (cf. especially pp. 61-73, 173-194).

7. Cf. for productive discussions on the connection between freedom, responsibility and visibility in Arrojo 1997 (stressing the power relations and hegemonic endeavour subtly working behind the ideal ethics of translation telling that translators should strive for scientific, objective, universal methods and strategies), Dizdar 1997, 2000 (re-reading and establishing connections between Vermeer's skopos theory and Gideon Toury's descriptive translation studies from a critical perspective), Niranjana 1992 (deconstructing traditional views both in translation studies and ethnographic writing about value-free, objective translation of cultures and texts) and Venuti 1995, 1998 (showing how the translator has been urged to become invisible through the idealization of fluent and unobtrusive translations reading like originals).

8. Her search for ways to develop didactic methods in order to teach translators this fundamental competence takes place against the background of modern functional translation theory and some theories of intercultural communication - the latter mainly from the 'first paradigm,' i.e. theories to be positioned within the social sciences approach, interestingly enough also entitled as the 'functional paradigm in intercultural communication studies' by Martin+Nakayama (1997: 27-30).

9. This line of thought is especially stressed in more recent studies on effects like sensitivization and consciousness-raising following culture shock situations (cf. i.e. Weaver 1994).

10. In my opinion, this point can be taken as a connection to approaches to (multi)cultural identities by theorists in the area of cultural studies like Stuart Hall (vgl. 1996a, 1996b) and Homi Bhabha (vgl. 1994a, 1994b; 1996).

11. I know very well that this aim is difficult to reach. The 'pains and aches' of attempts to advance the professionalization of interpreting services in medical and social settings within a cooperation network between Austria, Germany and Switzerland could very recently be experienced in the course of two workshops (at the Fachbereich Angewandte Sprach-und Kulturwissenschaft, Johannes Gutenberg-Universität Mainz in Germersheim, February 2000, and within the Gesundheitstag Berlin, June 2000), attended by practitioners as well as theoreticians engaged or interested in this area of interpreting (cf. Bahadır 2000).

\section{REFERENCES}

Adler, P. S. (1994): “Beyond Cultural Identity: Reflections on Cultural and Multicultural Man," in Weaver, G. (ed.) Culture, Communication and Conflict: Readings in Intercultural Communication, Needham Heights, MA, Simon and Schuster Custom Publishing, p. 241-259.

Albers, I. (1999): "Das phantomatische Herz Afrikas. Michel Leiris: Schreiben an den Grenzen der Ethnographie," KEA Zeitschrift für Kulturwissenschaften 12, p. 193-224.

Амвоrn, H. (1993): “Die Rückkehr der Ethik in die deutsche Ethnologie,” in AмвоRn, H. (ed.) Unbequeme Ethik. Überlegungen zu einer verantwortlichen Ethnologie, Berlin, Dietrich Reimer, p. 13-25. 
Ammann, M. (1995): Kommunikation und Kultur. Dolmetschen und Übersetzen heute. Eine Einführung für Studierende, Frankfurt/Main, Verlag für Interkulturelle Kommunikation.

Arrojo, R. (1997): "Asymmetrical Relations of Power and the Ethics of Translation," TEXTCONTEXT 11, p. 5-24.

Asad, T. (1986) "The Concept of Cultural Translation in British Social Anthropology," in Clifford + Marcus, p. 141-164.

BAHAdiR, Ş. (1998): “Der Translator als Migrant - der Migrant als Translator?" in TEXTconTEXT 12, p. 263-275.

Bahadir, Ş. (2000): "Von natürlichen Kommunikationskrücken zu professionellen Kommunikationsbrücken" (Reflexionen zum Berufsprofil und zur Ausbildung professioneller Dolmetscher im medizinischen, sozialen und juristischen Bereich)“, TEXTconTEXT 14-2, p. 211-229.

BARsky, R. F. (1996): “The Interpreter as Intercultural Agent in Convention Refugee Hearings,” in The Translator 2-1, p. 45-63.

Bauman, Z. (1997): Postmodernity and its Discontents, New York, New York University Press.

Bнавна, H. K. (1994a): "DissemiNation: time, narrative, and the margins of the modern nation," in Bнавна, H. K. (ed) Nation and Narration ( $3^{\text {rd }}$ edition), London/New York, Routledge, p. 291-322.

Bhabнa, H. K. (1994b): The Location of Culture. London/New York: Routledge.

Bнавна, H. K. (1996): “Culture's In-Between," in Hall, S. and P. DU GaY (eds.) Questions of Cultural Identity, London, p. 53-60.

Clifford, J. and G. E. Marcus (eds.) (1996): Writing Culture. The Poetics and Politics of Ethnography, Berkeley, University of California Press.

Clifford, J. (1988): The Predicament of Culture, Cambridge, Mass., Harvard University Press.

Derrida, J. (1990): "Structure, Sign, and Play in the Discourse of the Human Sciences," in Writing and Difference, (trans. A. Bass) London, Routledge.

Diriker, E. (1999): "Problematizing the discourse on interpreting - A quest for norms in simultaneous Interpreting," TEXTconTEXT 13-2, p.73-90.

Diriker, E. (2001): De-/Re-Contextualising Simultaneous Interpreting: Interpreters in the Ivory Tower?, Ph.D. Thesis, Istanbul, Bo?aziçi University, Department of Translation and Interpreting.

Dizdar, D. (1997): "Die Norm brechen - Möglichkeiten eines neuen Vokabulars in der Translationswissenschaft," TEXTconTEXT 11-2, p. 129-147.

Dizdar, D. (2000): "Descriptive Translation Studies (and beyond): Überlegungen aus und zu Tourys Theorie," TEXTconTEXT 14-1, p. 105-129.

Dwyer, K. (1979): “The Dialogic of Ethnology," Dialectical Anthropology 4-3, p. 205-224.

Fichte, H. (1988): "Ketzerische Bemerkungen für eine neue Wissenschaft vom Menschen," in Petersilie. Die afroamerikanischen Religionen. Santo Domingo, Venezuela, Miami, Grenada. Frankfurt/Main, Fischer.

Geertz, C. (1973): “Thick Description: Toward an Interpretive Theory of Culture," in The Interpretation of Cultures, New York, Basic Books, p. 3-30.

GöHring, H. (1976a): “Interaktionelle Leutekunde," in Drescher, H.W. und S. Scheffzek (eds.) Theorie und Praxis des Übersetzens und Dolmetschens. Referate und Diskussionsbeiträge des internationalen Kolloquiums am Fachbereich Angewandte Sprachwissenschaft der Johannes Gutenberg-Universität Mainz in Germersheim (2.-4. Mai 1975), Frankfurt, Peter Lang, p. 146158.

GöHring, H. (1976b): "Interkulturelle Kommunikationsfähigkeit," in Weber, H. (ed.) Landeskunde im Fremdsprachenunterricht. Kultur und Kommunikation als didaktisches Konzept, München, Kösel, p. 183-193.

Göhring, H. (1976c): "Kontrastive Kulturanalyse und Deutsch als Fremdsprache," in Jahrbuch Deutsch als Fremdsprache1 (2. überarbeitete Version), Heidelberg, Julius Gross Verlag, p. 8092. 
GöHring, H. (1977): "Sozialwissenschaftliche Anregungen für die Sprachlehrforschung," in Bender, K.-H., Berger, K. und M. Wandruszkan (eds.) Imago Linguae. Beitrage zu Sprache, Deutung und Übersetzen. Festschrift zum 60. Geburtstag von Fritz Paepcke, München, Wilhelm Fink Verlag, p. 169-177.

Göhring, H. (1978): "Interkulturelle Kommunikation: Die Überwindung der Trennung von Fremdsprachen- und Landeskundeunterricht durch einen integrierten Fremdverhaltensunterricht," in Kühlwein, W. und A. RaAsch (eds.) Kongreßberichte der 8. Jahrestagung der Gesellschaft für Angewandte Linguistik GAL e.V. Mainz 1977, Stuttgart, Hochschulverlag, p. 9-14.

GöHRING, H. (1980): "Deutsch als Fremdsprache und Interkulturelle Kommunikation," in Wierlacher, A. (ed) Fremdsprache Deutsch 1, München, Wilhelm Fink, p. 70-90.

Göhring, H (1998): "Interkulturelle Kommunikation," in Snell-Hornby, M., Hönig, H., Kussmaul, P. und P. A. Sснмiтt (eds.) Handbuch Translation, Tübingen, Stauffenburg.

Goffman, E. (1959): The Presentation of Self in Everyday Life, New York, Anchor Books, Doubleday.

Hall, S. (1996a): "Introduction. Who Needs. 'Identity”? “, in S. Hall and P. DU GaY (eds.) Questions of Cultural Identity, London.

Hall, S. (1996b): Critical Dialogues in Cultural Studies, London, New York, Routledge.

Häusler, C. (1999): "Reading Culture oder Die Authentizität der ethnographischen Lüge," in KEA Zeitschrift für Kulturwissenschaften 12, p. 241-256.

Heinrichs, H.-J. (1985): “Einleitung," in Leiris, M. Die eigene und die fremde Kultur. Ethnologische Schriften, Band 1 (Übers. R. Wintermeyer), Frankfurt/Main, Suhrkamp, p. 7-44.

Knoll, M. und F. Röder (1988): "Der Dolmetscher als Übersetzer, Berater und Mittler in der psychiatrischen Praxis," in Morten, A. (ed.) Vom heimatlosen Seelenleben. Entwurzelung, Entfremdung und Identität. - Der psychische Seilakt der Fremde. Bonn, Psychiatrie-Verlag, p. 109-130.

Leiris, M. (1985a): "Ethnographie und Kolonialismus," in Die eigene und die fremde Kultur. Ethnologische Schriften, Band 1 (trans. R. Wintermeyer), Frankfurt/Main, Suhrkamp, p. 53-71.

Leiris, M. (1985b): “Das Auge des Ethnographen," in Das Auge des Ethnographen. Ethnologische Schriften, Band 2 (trans. R. Wintermeyer) Frankfurt/Main, Suhrkamp, p. 29-25.

Lévi-Strauss, C. (1974): Tristes Tropiques (transl. John and Doreeen Weightman), New York, Atheneum.

Marcus, G. E. (1986): “Contemporary Problems of Ethnography in the Modern World System," in Clifford, J. and G. E. Marcus, p. 165-193.

Marcus, G. E. and M. Fischer (1986): Anthropology as Cultural Critique. An Experimental Moment in the Human Sciences, Chicago and London, The University of Chicago Press.

Martin, J. N. and T. Nakayama (1997): Intercultural Communication in Contexts. Mountain View, CA, Mayfield Publishing Company.

Morris, R. (1995) "The moral dilemmas of court interpreting," in The Translator 1-1, p. 25-46.

Niranjana, T. (1992): Siting translation: history, post-structuralism, and the colonial context, Berkeley/Los Angeles/Oxford, University of California Press.

Rosaldo, R. (1993): Culture and Truth. The Remaking of Social Analysis, Boston MA, Beacon Press.

Schweda Nicholson, N. (1994) "Professional Ethics for Court and Community Interpreters," in Hammond, D. L. (ed.) (1994): Professional Issues for Translators and Interpreters. American Translators Association Scholarly Monograph Series, Vol VII, Amsterdam/Philadelphia, John Benjamins, p. 79-97.

Toury, G. (1986): "Natural Translation and the Making of a Native Translator," TEXTconTEXT 1, p. 11-29.

Venuti, L. (1995): The Translator's Invisibility: A History of Translation, London/New York, Routledge.

Venuti, L. (1998): The Scandals of Translation. Towards an ethics of difference, London/New York, Routledge. 
Vermeer, H. J. (1985): “Was dolmetscht der Dolmetscher, wenn er dolmetscht?" in Rehbein, p. $475-482$.

VermeER, H. J. (1986): voraus-setzungen für eine translationstheorie - einige kapitel kultur- und sprachtheorie, Heidelberg.

WADENSJö, C. (1998a): Interpreting as Interaction, London and New York, Longman.

WAdENsjö, C. (1998b): "Erinnerungsarbeit in Therapiegesprächen mit Dolmetschbegleitung" (trans. Birgit Apfelbaum) in Apfelbaum, B. und H. Müller (eds.) Fremde im Gespräch. Gesprächsanalytische Untersuchungen zu Dolmetschinteraktionen, interkultureller Kommunikation und institutionalisierten Interaktionsformen, Frankfurt, IKO-Verlag.

Watzlawick, P., Beavin, J.H. and D.D. Jackson (1967): Pragmatics of Human Communication. A Study of Interactional Patterns, Pathologies, and Paradoxes, New York W.W. Norton.

Weaver, G. R. (1994): "Understanding and Coping with Cross-Cultural Adjustment Stress," in Weaver, G. R. (ed.) Culture, Communication and Conflict: Readings in Intercultural Relations. Needham Heights, MA: Simon \& Schuster Custom publishing, p. 169-189.

Weinberg, M. (1999): “Erbrechen Sie sich! Zu Hubert Fichtes, ketzerischen Bemerkungen für eine neue Wissenschaft vom Menschen," in KEA Zeitschrift für Kulturwissenschaften 12, p. 59-89.

Witte, H. (2000): Die Kulturkompetenz des Translators. Begriffliche Grundlegung und Didaktisierung, Tübingen, Stauffenburg Verlag.

Wolf, M. (1997): "Translation as a process of power: Aspects of cultural anthropology in translation," in Snell-Hornby, M., Jettmarová, Z. and K. Kaindl (eds.) Translation as intercultural communication: selected papers from the EST Congress, Prague 1995, Amsterdam, Philadelphia, John Benjamins. 